\title{
BOTANICAL AND GENETIC CHARACTERIZATION OF CITRUS MAXIMA (BURM.) MERRILL. F. RUTACEAE
}

\author{
MOHAMMED S. SEDEEK, FARID N. KIROLLOS, CAMILIA G. MICHEL, MOSTAFA A. ABDEL-KAWY \\ Pharmacognosy Department, Faculty of Pharmacy, Cairo University, Kasr El-Aini Street, Postal Code 11562, Cairo, Egypt \\ Email: fareed2011k@hotmail.com
}

Received: 03 Mar 2016 Revised and Accepted: 24 Nov 2016

\section{ABSTRACT}

Objective: Total investigation of the macro-and micromorphological features of Citrus maxima (Burm.) Merrill. In addition, DNA fingerprinting in this study was to estimate genetic polymorphism and relationships with another citrus viz: Citrus paradise and Citrus sinensis based on RAPD and ISSR markers.

Methods: For the establishment of macro-and micromorphological investigation and genetic estimation, this study presents a total investigation of the macro-and micromorphological features of the roots, stems, leaves, flowers, fruits and seeds of the plants through microscopical investigation of the prepared entire, transverse sections and powdered forms of different organs under study. Furthermore, the DNA of the three plants was extracted from leaf samples and two types of DNA markers RAPD and ISSR were assayed.

Results: Macro-and micromorphological features of different organs were investigated. On the other hand Genetic polymorphism and relationships among Citrus maxima, Citrus paradisi and Citrus sinensis was revealed. The highest genetic similarity was between Citrus maxima and Citrus paradisi while the lowest similarity was between Citrus paradisi and Citrus sinensis as revealed by RAPD, ISSR and combined data.

Conclusion: For the present study, macro and micro-morphological characters, as well as, DNA fingerprinting can be considered as the identifying parameters for authentication of Citrus maxima (Burm.) Merrill.

Keywords: Citrus, Maxima, Paradisi, Sinensis, Botanical profiling, DNA fingerprinting, RAPD, ISSR

(c) 2017 The Authors. Published by Innovare Academic Sciences Pvt Ltd. This is an open access article under the CC BY license (http://creativecommons.org/licenses/by/4. 0/) DOI: http://dx.doi.org/10.22159/ijpps.2017v9i1.11516

\section{INTRODUCTION}

The highly aromatic Rutaceae family (named for the bitter herb Rue), is most familiar from the genus Citrus and often called the Citrus family [1]. Citrus maxima is one of the most popular members that shows different pharmacological activities. It is a perennial shrub commonly known as pomelo or shaddock native to southeastern. It is a medium-sized tree but the largest of all Citrus species, with large leaves, flowers, and fruits. The tree is $5-15 \mathrm{~m}$ tall, with a somewhat crooked trunk 10-30 cm thick; branches low, irregular and spreading. Spines up to $5 \mathrm{~cm}$ long. Young branchlets angular, often densely soft, short, hairy, and usually with spines [2].

The authentication of the botanical identity of the herbal material has to be confirmed by molecular markers which have more advantages than that of morphologically based phenotypic characterization because molecular markers are generally unaffected by external impact. It is possible to compare accessions of a collection at any time of year using molecular markers, while phenotypic characteristics can be influenced by environmental or cultural affects.

Random amplified polymorphic DNA (RAPD) technique provides an approach to find polymorphisms within species or genetic differences between species based on the amplification of random DNA segments with single primers of arbitrary nucleotide sequence. These polymorphisms, simply detected as DNA segments which amplify from one parent but not the other, taken as a template [3]. The amplified fragments are separated on an agarose gel by electrophoresis to generate the DNA profiles.

Inter Simple sequence repeat (ISSR) fingerprinting was developed based on a repeat sequence, such as (CA) $n$, can be made with a degenerate 3'-anchor, such as (CA) 8RG or (AGC) 6TY. The resultant PCR reaction amplifies the sequence between two SSRs, yielding a marker system useful for fingerprinting, diversity analysis and genome mapping. [4] ISSRs have high reproducibility possibly due to the use of longer primers (16-25-mers) as compared to RAPD primers (10-mers), which permits the subsequent use of high annealing temperature $\left(45-60{ }^{\circ} \mathrm{C}\right)$ leading to higher stringency. [5] This technique overcomes most limitations such as low reproducibility and high cost. The objective of this study is to give a full macro-and micromorphological description as well as a DNA fingerprint to allow its identification in entire and powdered forms.

\section{MATERIALS AND METHODS}

Plant material

The roots, stems, leaves, flowers, fruits and seeds were collected from the Experimental Station for aromatic, medicinal and toxic plants, Faculty of Pharmacy, Cairo University, Giza, Egypt. The plants were kindly authenticated by Dr. Mohamed El-Gebaly, senior botanist; National Research Center and agriculture engineer Mrs. Therese Labib, senior botanist, El-Orman botanical garden, Giza, Egypt. Voucher specimens were kept at the Herbarium of the Department of Pharmacognosy, Faculty of Pharmacy, Cairo University.

\section{Botanical profiling}

Photographs for macro and micromorphological study were taken using Canon power shot A470 digital camera and Leica DFC500 digital camera, respectively. Samples of the roots, stems, leaves, flowers, fruits and seeds were separated and examined either fresh or after keeping in ethanol (70\%) containing 5\% glycerol, as well as after being dried and reduced to fine powder for microscopical examination.

\section{Genetic profiling}

Fresh leaves samples of Citrus maxima, Citrus paradise and Citrus sinensis were collected for RAPD and ISSR analysis, freeze-dried, and ground to fine powder in liquid nitrogen prior DNA isolation. The analysis was performed at the Agricultural Research center, Faculty of Agriculture, Cairo University. 


\section{DNA isolation}

From each accession, four young leaves were taken, and total genomic DNA was extracted according to Doyle and Doyle with some modifications [4-15]. The leaves were ground to a fine powder in liquid nitrogen, and $200 \mathrm{mg}$ of fresh ground leaves were mixed with $1 \mathrm{ml}$ of preheated $\left(65{ }^{\circ} \mathrm{C}\right)$ extraction buffer $(2 \%$ hexadecyltrimethylammonium bromide [CTAB: Sigma H-5882], $1.4 \mathrm{M} \mathrm{NaCl}$, $0.2 \%$ 2-mercaptoethanol, $20 \mathrm{mmol}$ EDTA, $100 \mathrm{mmol}$ Tris- $\mathrm{HCl}, \mathrm{pH}$ 8.0). Mixtures were incubated at $65^{\circ} \mathrm{C}$ for $30 \mathrm{~min}$ and then extracted with chloroform-octanol (24:1). Mixtures manually shocked for 5 min. aqueous phases containing DNAs were separated by centrifugation for $10 \mathrm{~min}, 2500 \mathrm{rpm}$, and then transferred to $2 \mathrm{ml}$ clean tubes. Nucleic acids were precipitated by adding 2 to 3 of their volumes of cold absolute ethanol and centrifugation for $10 \mathrm{~min}$, $5000 \mathrm{rpm}$. Nucleic acids were then washed twice with $76 \%$ ethanol with $10 \mathrm{mmol}$ ammonium acetate and centrifugation for $5 \mathrm{~min}, 5000$ rpm after each washing step. After brief air-drying, DNA pellets were resuspended in $300 \mu \mathrm{l} \mathrm{TE}(10 \mathrm{mmol}$ Tris-HCl, 1 mmol EDTA, $\mathrm{pH}$ 7.4) and kept at-20 ${ }^{\circ} \mathrm{C}$ until use. DNA concentration was measured spectrophotometrically (Nano Drop 1000, USA) at $260 \mathrm{~nm}$ and DNA templates were diluted to $50 \mathrm{ng} / \mu \mathrm{l}$.

\section{PCR Amplification and electrophoresis}

RAPD Marker's primers obtained from Bio Basic Inc., were used in PCR reactions. Each PCR reaction contained 100 ng of DNA template, $200 \mu \mathrm{M}$ of dNTPs, $0.4 \mu \mathrm{M}$ of Operon primer, $5 \mu \mathrm{l}$ of $10 \mathrm{X}$ of PCR buffer with $1.5 \mathrm{mmol}$ of $\mathrm{MgCl}_{2}$ and one unit of Taq DNA polymerase, in a final volume of $25 \mu \mathrm{l}$. PCR program conditions consisted of $94{ }^{\circ} \mathrm{C}$ for $5 \mathrm{~min}$, then 35 cycles of $94^{\circ} \mathrm{C}$ for 1 min followed by $37^{\circ} \mathrm{C}$ for 1 $\min$ and $72{ }^{\circ} \mathrm{C}$ for $3 \mathrm{~min}$. and one cycle at $72{ }^{\circ} \mathrm{C}$ for $7 \mathrm{~min}$.

\section{DNA electrophoresis}

Amplified PCR products were separated by electrophoresis (5 Vcm) in $1.5 \%$ agarose gels and stained with $0.5 \mathrm{ml}$ of ethidium bromide. A photographic record was taken under UV transilluminator (using Gell documentation camera).

\section{Data analysis}

Each DNA amplified fragment was scored as present (1) or absent (0) Fragment or alleles, respectively and data were analysed with the Numerical Taxonomy Multivariate Analysis 1 System (NTSYS-pc) software package version 2.02. Cluster analysis was done by unweighting pair group's method arithmetic average (UPGMA) with Jacquard similar coefficient.

\section{RESULTS AND DISCUSSION}

\section{Botanical profiling}

Macro-morphology of Citrus maxima (Burm.) Merrill. (fig. 1)

The root

The underground part of the plant (fig. 1A) was formed of two types; the first, the large pioneer roots radiate out in all directions forming the framework of lateral roots, dark yellowish brown to pale brown in color with a rough surface and measuring $1-3 \mathrm{~cm}$ in diameter. The second, fine fibrous roots emanating in bunches from woody lateral roots, the primary sites where water and nutrient uptake from soil occurs. They were yellowish brown to pale brown in color, measuring $0.2-0.8 \mathrm{~cm}$ in diameter and extended to $30-90 \mathrm{~cm}$ laterally below the soil.

\section{The stem}

Old stem (fig. 1B) short, erect, cylindrical, woody, stiff, yellowish brown with monopodial branching, showing fine longitudinal striations and longitudinal furrows.

Young stem (fig. 1C) green, cylindrical and smooth, showing internodes measuring $3-5 \mathrm{~cm}$ long.

\section{The leaf}

The leaf (fig. 1D) cauline insertion with alternate phyllotaxis, simple, ovate-lanceolate in shape, petiolate with crenate margin,

emarginated apex, symmetric base with smooth, glossy surfaces. The upper surface was green, darker than the lower with pinnate reticulate venation. The midrib was more prominent on the lower surface and the lamina size is measuring $5-20 \mathrm{~cm}$ in length and $2-12$ $\mathrm{cm}$ in width. The petiole was winged, green in color, $2-4 \mathrm{~cm}$ long, and $2-2.5 \mathrm{~cm}$ in diameter.

\section{The flower}

The flower (fig. 1E) actinomorphic, hermaphrodite, with the floral formula.

$$
\bigoplus, \underset{f}{q}, \mathrm{~K}_{(4-5)}, \mathrm{C}_{4-5}, \mathrm{~A}_{(10-\infty),} \mathrm{G}_{(2-5)}
$$

The inflorescence was cymose and the flower was fragrant, pedicellate, borne singly. Calyx was hairy and persistent with 4-5 united green coloured sepals. Corolla was of 5 free yellowish-white petals, 1.5-3.5 cm long, dotted with yellow-green glands. Androecium had many polyadelphous stamens. Gynoecium had 2-5 united carpels (syncarpous), multilocular (locules as many as carpels) with many ovules, axile placentation, superior ovary, lobed style and with small stigma.

\section{The fruit}

The fruit (fig. 1F) hesperidium (true, simple, succulent, berry with leathery epicarp) ranging from nearly round to pear-shaped; 10-30 $\mathrm{cm}$ in diameter; the peel, clinging or more or less easily removed, may be orange or pale yellow.

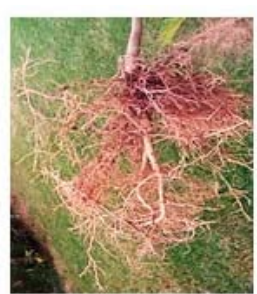

A

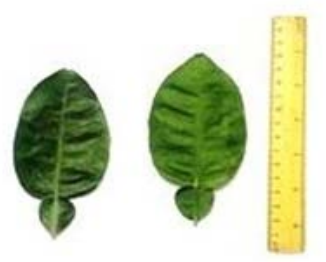

D

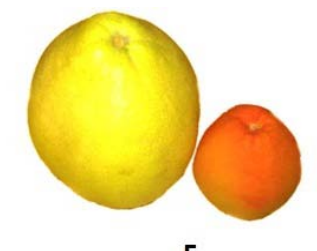

F
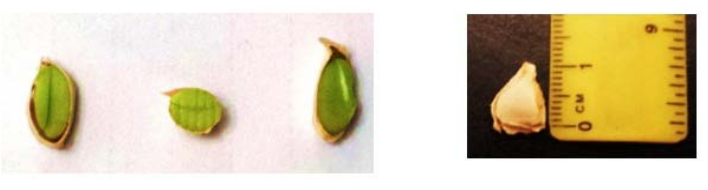

G

Fig. 1: Photographs of root, stem, leaf, flower, fruit and seed of Citrus maxima (Burm.) Merrill. (A) Root (X=0.15) (B) Old stem $(X=0.2)$ (C) young stem (0.15) (D) upper and lower surface of leaf $(X=0.1)(E)$ Flower $(X=1.8)(F)$ Fruit yellow and orange cultivars $(X=0.2)(G)$ Seed $(x=1.5)$ 
Its surface was shiny yellow and granular due to the presence of many oil glands, minutely hairy, the albedo (outer yellow or orange colored part of rind called flavedo and inner white part called albedo) soft, white or pink; pulp varies from greenish-yellow or pale yellow to pink or red; divided into 11-18 segments, very juicy to fairly dry; the segments were easily skinned and the sacs may adhere to each other or be loosely joined. Fruits had an aromatic, fragrant odor and a bitter taste.

\section{The seed}

The seed (fig. 1G) derived from an anatropous ovule, ovate, somewhat flattened and showing rounded end at one side with an acute apex. Hilum and micropyle are close to each other situated in a depression near the acute apex. The raphpresent and extends as raised pale yellow line along the acute edge from the hilum to the chalaza end. It measures $0.4-0.7 \mathrm{~cm}$ long and 0.3-0.5 cm wide.

Testa was yellow in colour, brittle and encloses large straight embryo, formed of the outer coat which is tough, leathery, strawcolored and slippery when wet, and inner coat, which is thin dry and light-brown, the embryo was formed of two large, straight and plano-convex cotyledons and a small radicle.

A longitudinal cut in the seed shows yellow testa surrounding two large green fleshy cotyledons. The radicle was small, straight and apical. The seeds were exalbuminous, odourless and had an oily bitter taste.

\section{Micro-morphology of Citrus maxima (Burm.) Merrill}

\section{The root (fig. 2)}

A transverse section of the root is circular in outline, showing an outer narrow pale brown suberized cork followed by a narrow cortex surrounding the wide stele. The secondary cortex (phelloderm) consists of tangentially elongated parenchymatous cells, primary cortex formed of parenchyma cells showing narrow intercellular spaces, containing numerous calcium oxalate prisms and traversed by schizo lysigenous oil glands.

The endodermis is indistinct followed by a parenchymatous pericycle with patches of pericyclic fibres. The pericyclic fibres are surrounded by distinct crystal sheath. The vascular tissue is formed of xylem which is wholly dignified, formed of vessels, tracheids, wood fibers and wood parenchyma followed to outside by cambium then phloem region which consists of thin walled parenchymatous cells, phloem fibers and uniseriate with rarely biseriate medullary rays.

\section{Powdered root (fig. 3)}

Powdered root is brownish yellow having a characteristic odor and a slightly bitter taste. It is characterised microscopically by the presence of the following features: fragments of wood fibers, lignified vessels, pitted tracheids, medullary rays' cells, pericyclic fibers, phloem fibers, crystal sheath, scattered prisms of calcium oxalate, idioblasts containing prismatic crystals of calcium oxalate and brown cork cells.

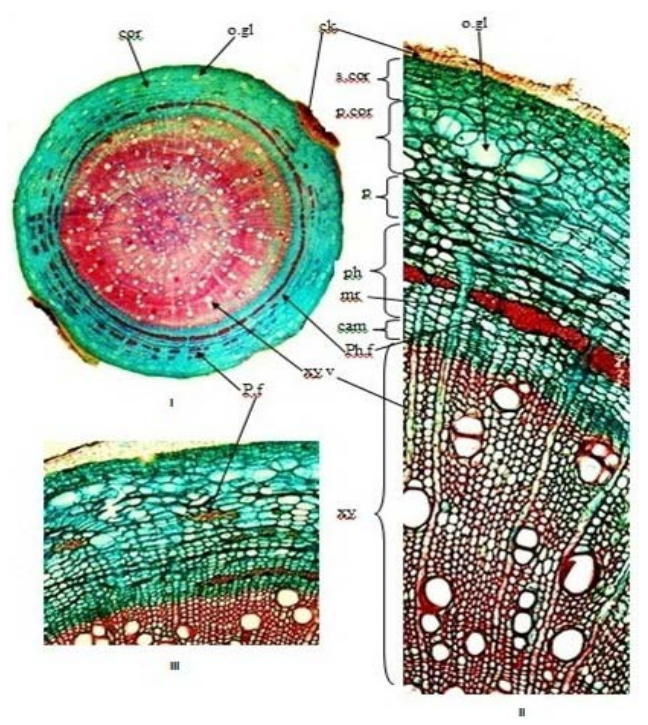

Fig. 2: Micromorphology of $C$. maxima root. (I) Low power view of root T. S. ( $\mathrm{X}=20$ ), (II) High power view of root T. S. (X=100), (III) High power view of root $T$. S. $(X=100)$, ck., cork cells; cr. sh., crystal sheath; mr., medullary rays; p f., pericycle fibers; pr., prisms of calcium oxalate; tr., tracheid; w. f., wood fibers; $x y$. v., xylem vessels

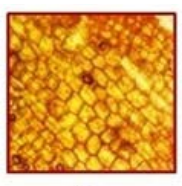

A

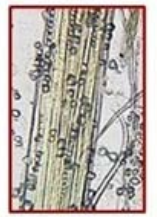

D

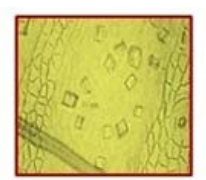

B
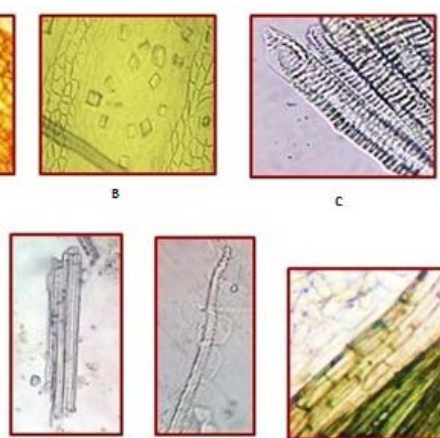

E

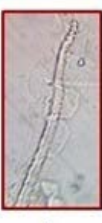

$\mathrm{F}$

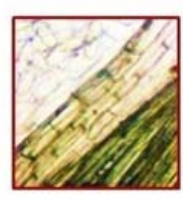

G

Fig. 3: Powdered root A., cork ( $X=100)$; B., crystals of Caox. $(X=160)$; C., tracheid $(X=400)$; D., Crystal sheath ( $X=160)$; E., Wood fibers. $(X=160)$; F., Pericycle fibers ( $X=400) ;$ G., Medullary rays $(X=160)$ 


\section{The stem}

\section{Young stem (fig. 4)}

A transverse section in a young stem is more or less circular in outline. It shows an epidermis, followed by relatively wide cortex, which is traversed by schizo lysigenous oil glands and contain scattered prismatic crystals of calcium oxalate. The endodermis is indistinct. The pericycle consists of large groups of pericyclic fibers interrupted by thin-walled parenchyma cells surrounding a continuous vascular cylinder enclosing wide parenchymatous pith. The epidermis consists of polygonal cells with straight thin cellulosic anticlinal walls and covered by a thick smooth cuticle, showing unicellular, non-glandular hairs and anormocytic stomata. The cortex is formed of 10-12 rows of thin-walled parenchyma cells, traversed by schizo lysigenous oil glands and large idioblasts containing calcium oxalate prisms. The pericycle consists of large groups of pericyclic fibers interrupted by thin-walled cellulosic parenchyma cells, fibers are surrounded by distinct crystal sheath. The vascular tissue formed of phloem which consists of thin walled phloem elements and prismatic crystals of calcium oxalate followed by cambium which is formed of radially arranged thin-walled cells then xylem which consists of vessels, tracheids, wood fibers and wood parenchyma. The pith: consists of rounded parenchyma having thin-cellulosic walls, containing numerous prismatic crystals of calcium oxalate.

\section{The old stem}

A transverse section in the old stem is nearly similar to that of the young stem but showing the following main differences:

-Large xylem region occupying about $2 / 3$ of T. S diameter and narrower pith.

-The pericycle is formed of parenchymatous cells interrupted by patches of fibers.

-The phloem contains lignified phloem fibers.

\section{Powdered stem (fig. 5)}

The powdered stem is yellowish green to pale green with characteristic slight aromatic odor and slightly bitter taste. Microscopically it is characterised by the presence of the following features: Fragments of thick walled epidermis showing anomocytic stomata and non-glandular trichomes of unicellular and multicellular uniseriate types, numerous idioblasts with prismatic crystals of calcium oxalate, pericyclic fibers, crystal sheath, tracheids and vessels.

\section{The leaf (fig. 6)}

A transverse section in the leaf is bi-convex in midrib region, being more prominent on the lower side. It shows a dorsiventral arrangement, exhibiting upper and lower epidermises, enclosing in between a heterogeneous mesophyll. It shows two rows of palisadelike cells, traversed by schizo lysigenous oil glands and interrupted by idioblasts. The spongy tissue is traversed by schizo lysigenous oil glands, small vascular bundles and contains scattered prismatic crystals of calcium oxalate.

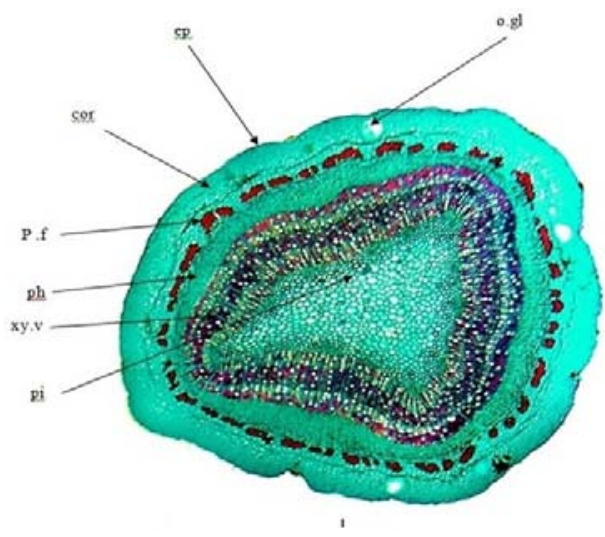

Fig. 4: Micromorphology of C. maxima stem (I) Low power view of young stem T. S. $(X=20)$
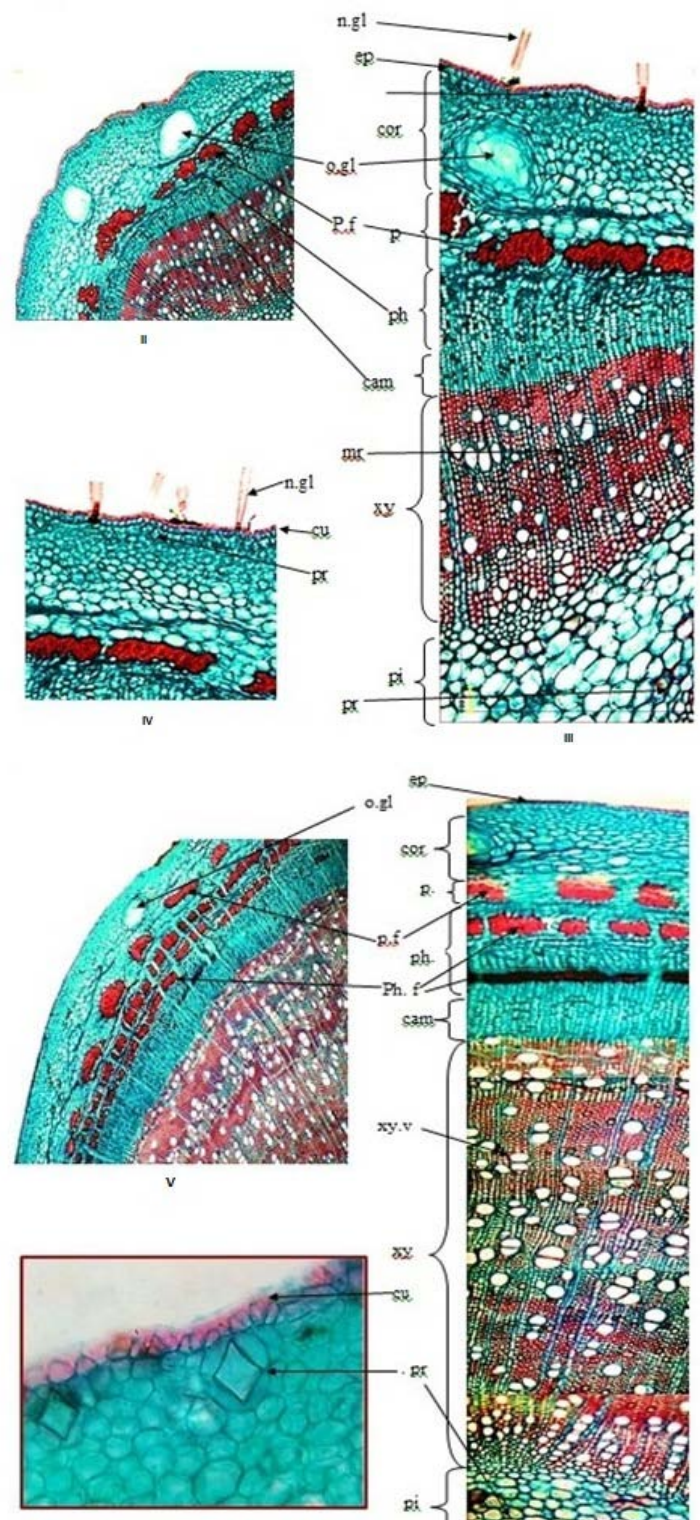

vi1

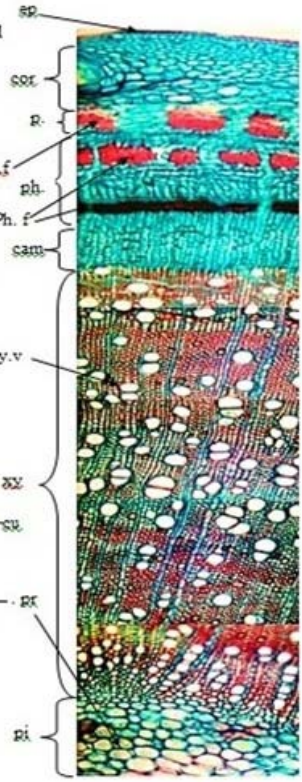

Fig. 4: Micromorphology of C. maxima stem (II) High power view of young stem T. S. (X=100), (III) High power view of young stem T. S. showing oil gland ( $X=60$ ), (IV) High power view of young stem T. S. showing non-glandular hair $(X=100)$, (V) High power view of old stem T. S. (X=60),(VI) High power view of old stem T. S. $(X=100),(\mathrm{VII})$ High power view of old stem T. S. ( $X=640$ ),cor., cortex; cam., cambium; cu., cuticle; ep., epidermis; o. gl., oil gland; p. f., pericycle fibers; ph., phloem; ph. f., phloem fibers; pi., pith; pr., the prism of Caox; xy., xylem; xy. v., xylem vessels

\section{The upper epidermis}

Consists of tabular parenchyma cells covered by thick, smooth cuticle. They are polygonal cells having straight to slightly wavy anticlinal walls, showing non-glandular unicellular and multicellular trichomes and no stomata. Large parenchymatous cells containing calcium oxalate occur in the palisade layer and protrude into the epidermis (idioblasts)

\section{The lower epidermis}

Similar to the upper but with wavier anticlinal walls, showing anomocytic stomata and non-glandular unicellular and multicellular trichomes. 


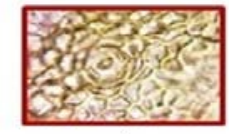

A

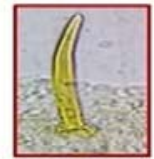

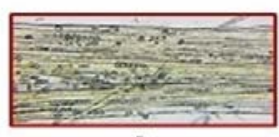
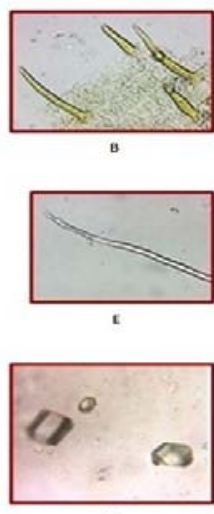
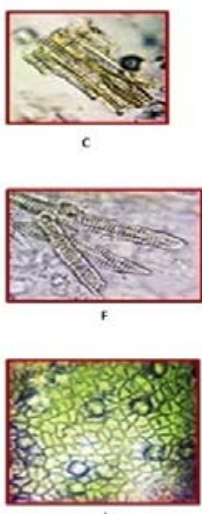

Fig. 5: Powdered stem A., anomocytic stomata. $(X=400)$; B., nonglandular hairs. $(X=100)$; $C$., xylem vessels. $(X=100)$; $D .$, crystal sheath. $(X=160)$; E., tracheids. $(X=160), F$., pericycle fiber.

$(X=160)$; G., non-glandular hair. $(X=160)$; H., a prismatic crystal of Caox. $(X=400)$, I., epidermal cells showing Caox prisms. $(X=160)$

\section{The lamina region}

It is differentiated into upper palisade and spongy tissue. The palisade tissue consists of three layers; the cells of the third layer are shorter than the first and second. The palisade cells are interrupted by large idioblasts. The spongy tissue consists of nearly rounded cells showing intercellular spaces, schizo lysigenous oil glands, small vascular bundles and scattered calcium oxalate prisms.

\section{The midrib region}

Cortical tissue consists of rounded parenchymatous cells enclosing large circular concentric vascular bundle. Numerous schizo lysigenous oil glands, calcium oxalate crystals are scattered in the cortical tissue. The pericycle is formed of a ring of fibers interrupted by small groups of parenchymatous cells each containing prismatic crystals forming crystal sheath. The phloem consists of thin cellulosic phloem parenchyma, sieve tubes and companion cells. It is traversed by medullary rays similar to that of the root. The xylem: consists of vessels, tracheids, wood fibers and wood parenchyma. The pith is formed of rounded parenchyma cells.

\section{The petiole transverse section}

Shows a more or less circular outline and similar to that of the lamina of the leaf but differs in having wider cortical tissue and smaller patches of lignified pericyclic fibers.

\section{Powdered leaf (fig. 7)}

Powdered leaf is green in color with aromatic odor and slightly bitter taste. Microscopically, it is characterized by the presence of following: Fragments of upper epidermis with straight walls covered with smooth cuticle, showing non-glandular trichomes similar to those of the stem and oil glands, fragments of Lower epidermal cells with straight walls, covered by smooth cuticle and contain anomocytic stomata, fragments of broken lignified vessels, tracheids, pericyclic fiber, crystal sheath, numerous prismatic crystals of calcium oxalate, palisade cells and non-glandular warty hair.

\section{The flower (fig. 8)}

The microscopical examination of the different segments of the flower viz., sepals, petals, androecium, gynoecium and pedicle revealed the following:

\section{The sepal}

A transverse section shows outer and inner epidermises, enclosing a homogenous mesophyll, traversed by numerous small vascular strands, prismatic crystals of calcium oxalate and schizo lysigenous oil glands. The outer epidermis consists of one layer of rounded papillose, thick-walled cells with wavy striated cuticle showing numerous non-glandular, unicellular and multicellular uniseriate trichomes. Unicellular trichome is conical, curved or thumb-like.
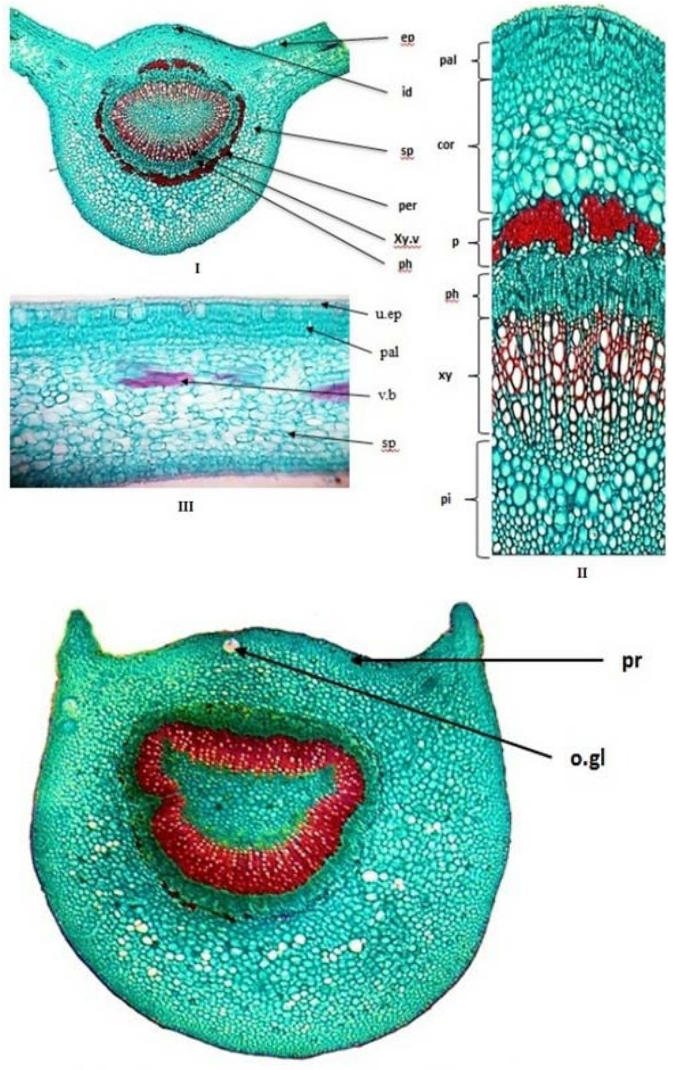

IV

Fig. 6: Micromorphology of $C$. maxima leaf. (I) Low power view of leaf T. $S$. $(X=20)$, (II) High power view of midrib region in leaf T. S. $(X=100)$, (III) High power view of lamina region in leaf T. $S$. $(X=160)$, (IV) High power view of petiole T. $S$. $(X=20)$. cor., cortex; cu., cuticle; mr., medullary rays; $n$. gl., non-glandular hair; o. gl., oil gland; pal., palisade cells; p., pericycle; p. f., pericycle fibers; ph., phloem; pi., pith; pr., Caox prisms; sp., spongy tissue; u. ep., upper epidermis; v. b., vascular bundle; xy., xylem; xy. v, xylem vessels

\section{The petal}

A transverse section in the petal is more or less similar to that of the sepal, but differs in being thicker, having more oil glands and showing no trichomes.

\section{The androecium}

A transverse section in the anther shows four pollen sacs containing numerous pollen grains. The anther wall is formed of an epidermis and a fibrous layer. The fibrous layer is formed of one row of radially elongated cells showing bar-like thickening. The pollen grains are spherical in shape and have four germ pores and smooth exine.

\section{The gynoecium}

\section{The ovary wall}

A transverse section in the ovary wall shows an outer and inner epidermises enclosing parenchymatous mesophyll, traversed by numerous small vascular bundles and calcium oxalate prisms.

\section{The style}

A transverse section in style is rounded in outline, showing an epidermis, followed by cortical tissue, traversed by slit-shaped stylar canals, small vascular bundles, and numerous prismatic crystals of calcium oxalate and schizo lysigenous oil glands. These bundles are located between the style canals. 


\section{The stigma}

Shows epidermis formed of rounded polygonal, papillosed cells and thick-walled with wavy striated cuticle and numerous prismatic crystals of calcium oxalate.

\section{The pedicle}

A transverse section in the pedicle is rounded in outline. It is formed of an epidermis, followed by parenchymatous cortex, traversed by few discontinuous collateral vascular bundles, schizolysigenous oil glands and enclosing parenchymatous pith at the center.

\section{The epidermis}

Formed of polygonal axially elongated cells having a straight anticlinal wall, showing striated cuticle, anomocytic stomata, trichomes, schizolysigenous oil glands and calcium oxalate crystals similar to those of the sepals.

\section{Powdered flower (fig. 9)}

The powdered flower is yellowish green in color having an aromatic odor and aromatic slightly bitter taste. Microscopically it is characterized by presence of the following: numerous non-glandular trichomes, unicellular either conical, curved or thumb-like and covered with thick warty cuticle, numerous prismatic crystals of calcium oxalate, fragments of the outer epidermis of the sepals with rounded polygonal cells, papillose, thick walls with wavy striations in the cuticle, Fragments of the epidermis of the petals, rounded polygonal cells, papillosed, thick walls with wavy striations in the cuticle, fibrous layer of the anther, lignified vessels, pollen grains, fragment of stigma with papillosed cells.

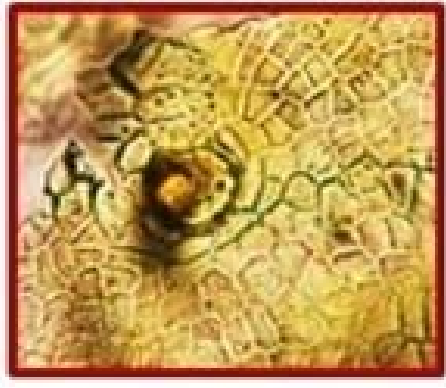

A

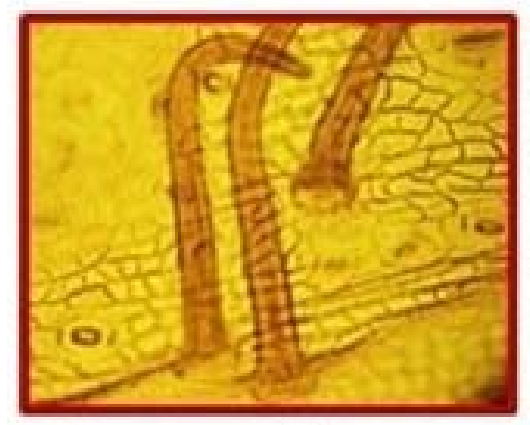

D

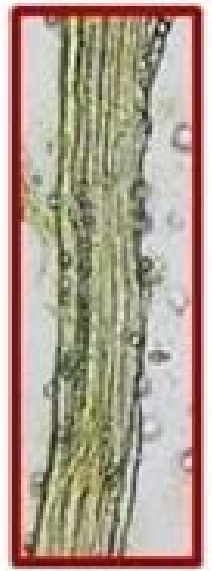

G

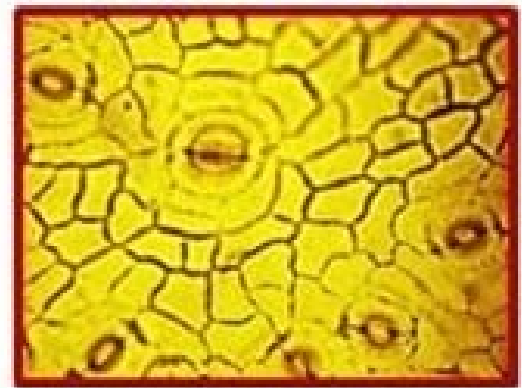

B

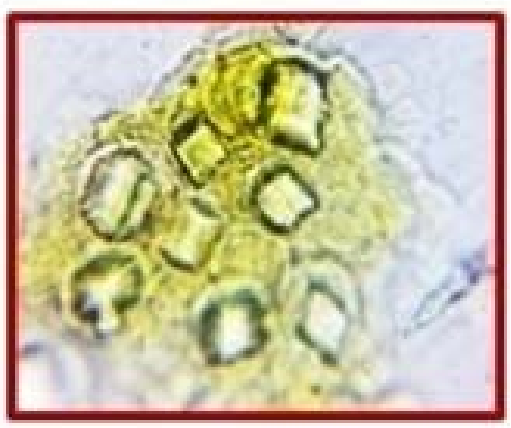

E

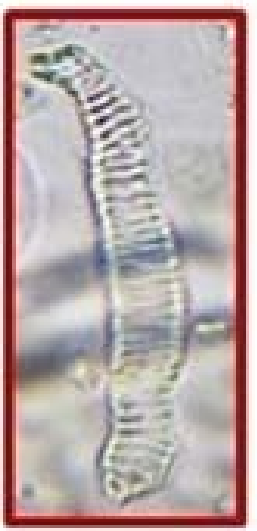

I

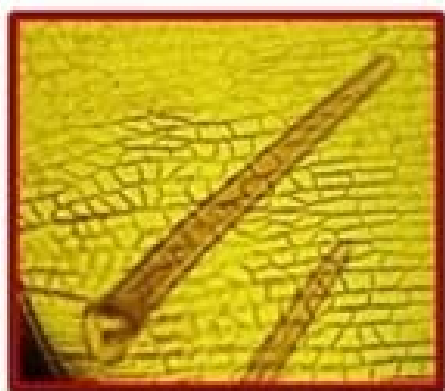

C

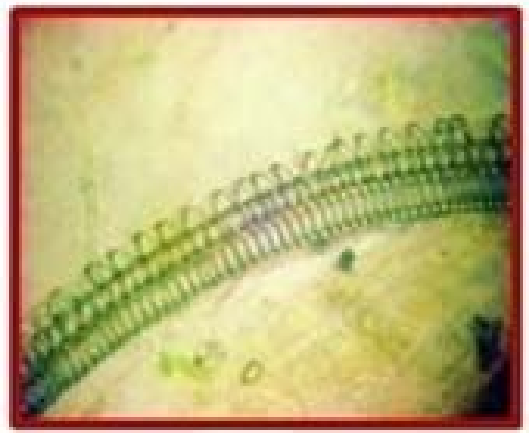

$\mathbf{F}$

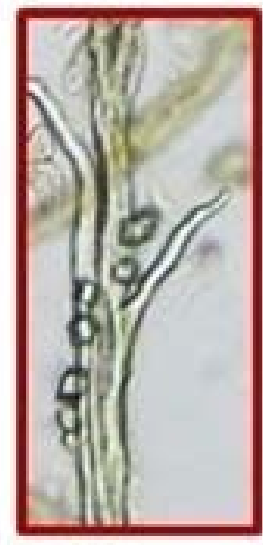

$\mathrm{H}$

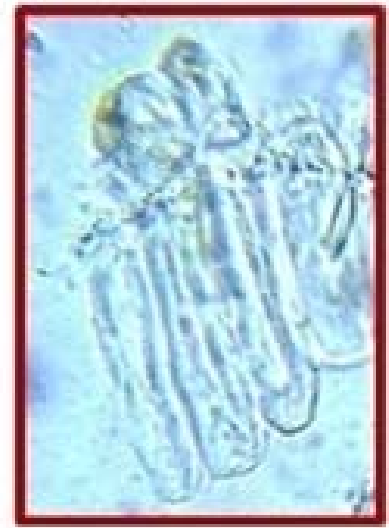

$\mathbf{J}$

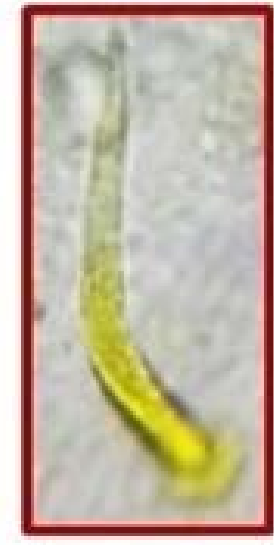

K

Fig. 7: Powdered leaf A., oil gland $(X=400)$; B., anomocytic stomata $(X=400)$; C., non-glandular hairs $(X=400)$; $D$. , anomocytic stomata and non-glandular hairs. $(X=400)$; E., prismatic crystals of Caox. $(X=640)$; $F$., $X y l e m$ vessels. $(X=400)$; $G$., $C r y s t a l$ sheath. $(X=160)$, $H .$, pericycle fiber ( $X=160)$; I., tracheid. $(X=160)$; J., palisade cells. $(X=400)$; $K .$, non-glandular unicellular warty hair. $(X=400)$ 

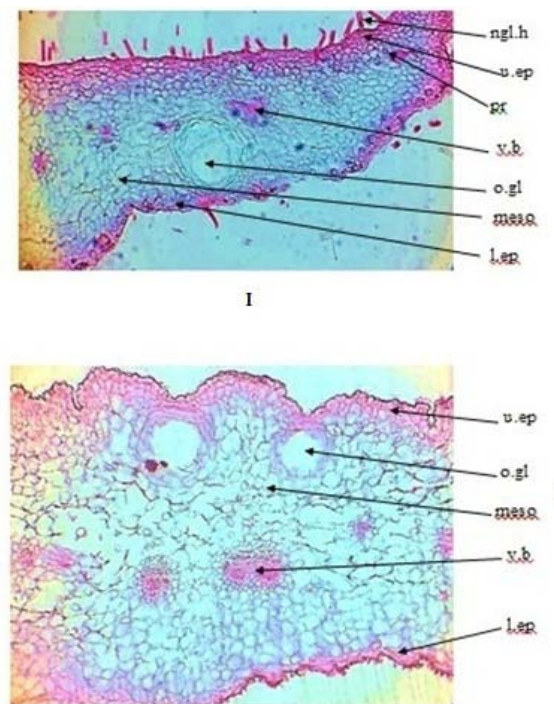

II

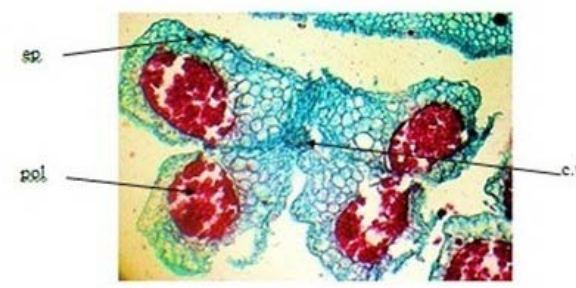

III

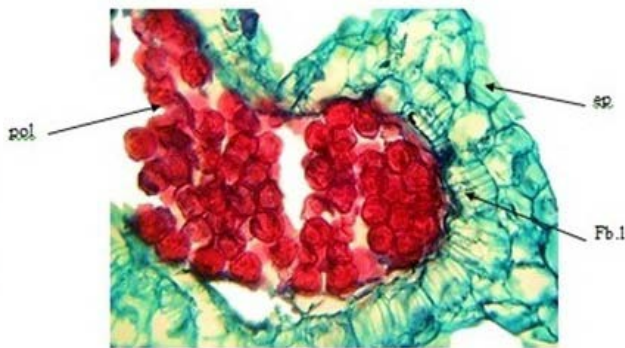

IV
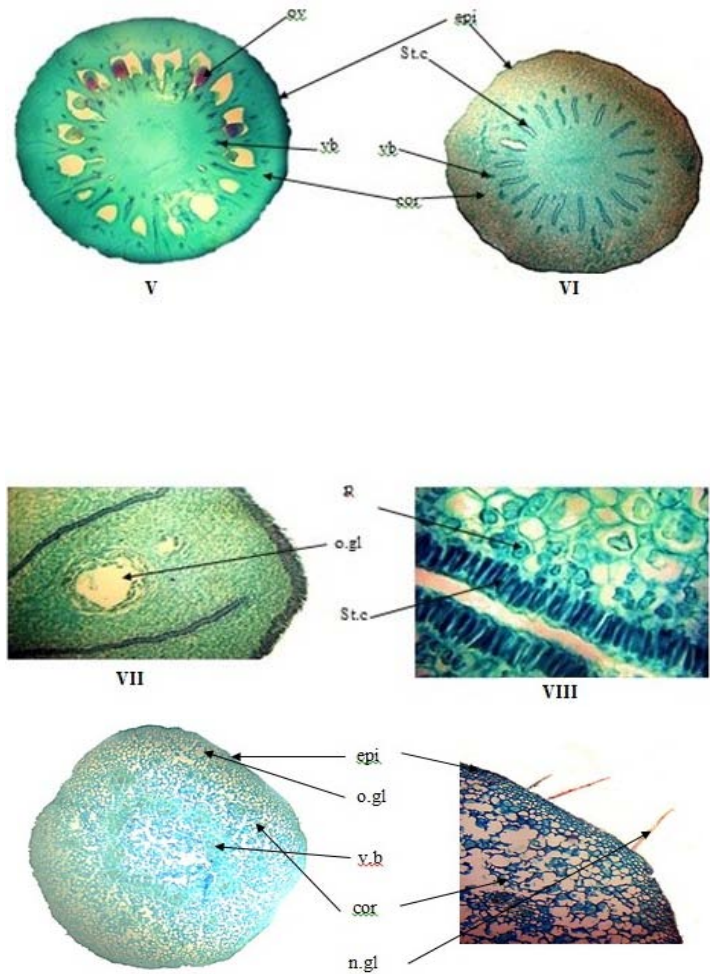

$\mathbf{I X}$

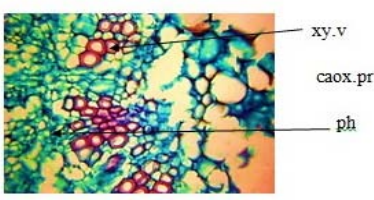

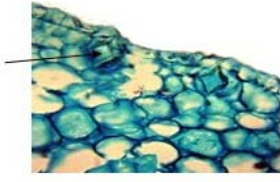

Fig. 8: Micromorphology of $C$. maxima flower. (I) Low power view sepal T. S. (X=50), (II) High power view of petal T. S. (X=100), (III) Low power view of anther T. S. (X=50), (IV) High power view of anther T. S. $(X=200)$, (V) Low power view of ovary T. S. (X=20), (VI) Low power view of style T. S. (X=20), (VII) High power view of style oil gland T. S. $(X=400)$,(VIII) High power view of style canal T. S. (X=400), (IX) Low power view of pedicle T. S. $(X=20)$, (X) High power view of non-glandular hair in pedicle T. S. $(X=400)$, (XI) High power view of vascular bundle in pedicle T. S. (X=400), (XII) High power view of prisms of Ca Ox in pedicle T. S. (X=400). caox. pr., prism of calcium oxalate; cor., cortex; c. t. connective tissue; ep., epidermis; fb. l., fibrous layer; n. gl., non-glandular hair; o. gl., oil gland; ov., ovule; ph., phloem; Pol., pollen grains. St. c, style canal; vb., vascular bundle; $\mathrm{xy}$. v., xylem vessels 


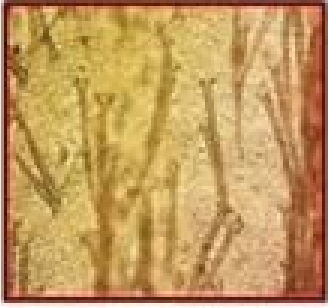

A

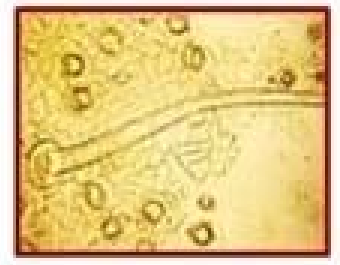

E

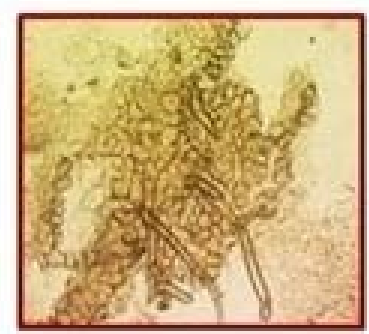

I

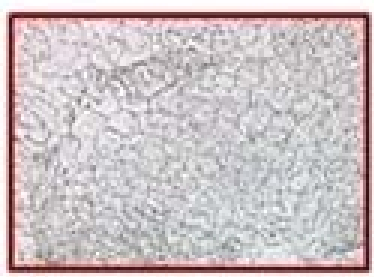

M

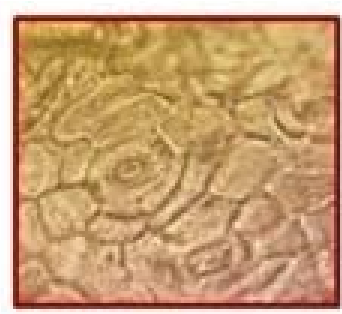

B

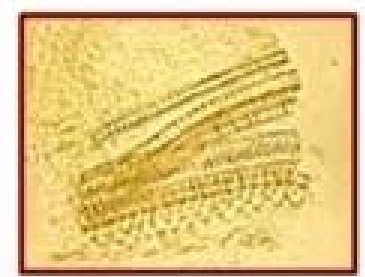

F

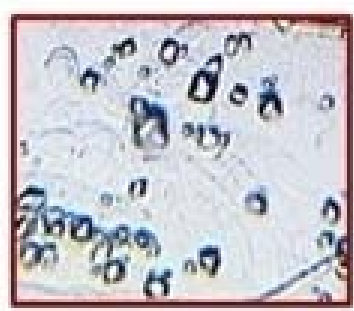

J

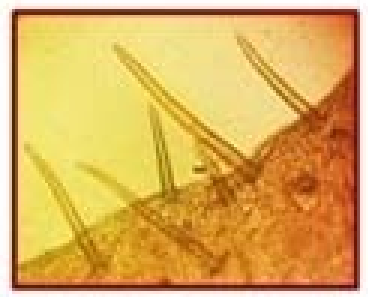

$\mathrm{N}$

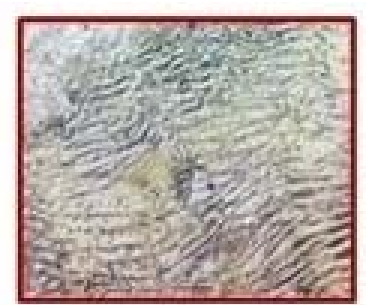

C

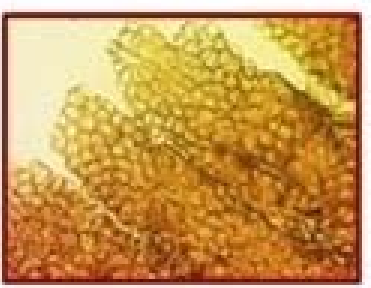

G

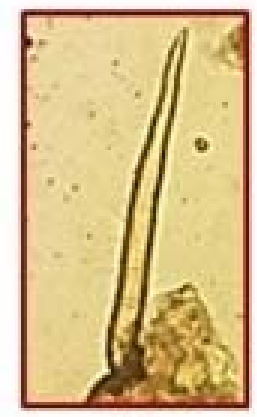

K

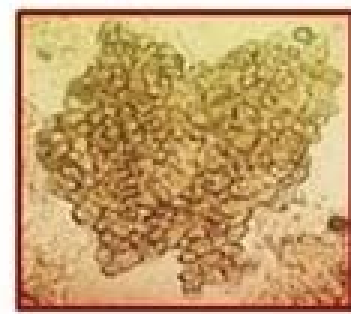

D

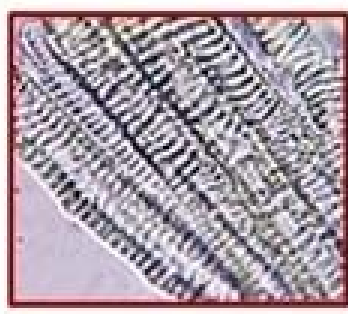

H

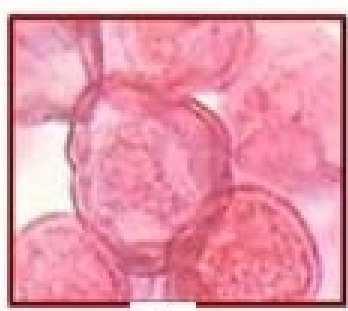

L

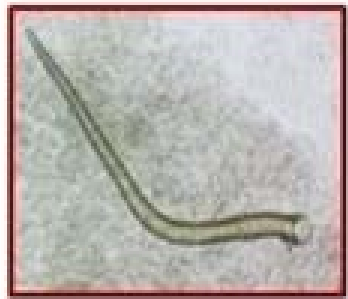

o

Fig. 9: Powdered flower A., non-glandular hairs ( $X=100)$; B., anomocytic stomata $(X=400)$; $C$., fibrous layer of the anther $(X=400)$; $D .$, petal epidermis ( $X=400)$; E., non-glandular unicellular hair with prisms of Caox. $(X=400)$; F., Xylem vessels. $(X=160)$; $G$., sepal epidermal cells. $(X=400)$, $H$., $x y l e m$ vessels $(X=160)$; $I$. , petal epidermis with non-glandular hairs $(X=400)$; J., prismatic crystals of Caox. $(X=160)$; $K$., Nonglandular unicellular hair ( $X=640)$; $L$., pollen grain showing four germ pores $(X=640)$; $M$., papillose cells of stigma $(X=400)$; $N$., sepal epidermis with non-glandular hairs. $(X=100) ; 0 .$, Non-glandular unicellular ovary hairy curved in shape with thick striated cuticle. $(\mathrm{X}=\mathbf{4 0 0})$

The fruit: (fig. 10)

\section{The pericarp (The rind)}

A transverse section formed of an outer epicarp (thin leathery layer) and an inner endocarp (thin membranous layer) enclosing the mesocarp (thick and fleshy layer). The mesocarp is traversed by vascular bundles, schizo lysigenous oil glands and scattered calcium oxalate prisms.

\section{The epicarp (flavedo)}

Consists of tabular parenchyma cells covered with thick, smooth cuticle; they are polygonal isodiametric, thick and straight anticlinal walls, striated cuticle and showing anomocytic stomata, idioblasts and oil glands.

\section{The mesocarp (albedo)}

Formed of polygonal parenchyma cells, showing air spaces and vascular bundles.

\section{The endocarp}

The endocarp is separated into segments; these segments are filled with juice vesicles, which contain the juice of the fruit.

The endocarp is a membranous parenchymatous cells.

\section{Powdered fruit (fig. 11)}

Powdered fruit is yellow to yellowish green in color having a characteristic aromatic odor and aromatic slightly bitter taste.

Microscopically it is characterised by the presence of fragments of polygonal cells of the epidermis with straight anticlinal walls, showing striated cuticle and anomocytic stomata, lignified xylem vessels, numerous prismatic crystals of calcium oxalate and unicellular non-glandular hairs. 


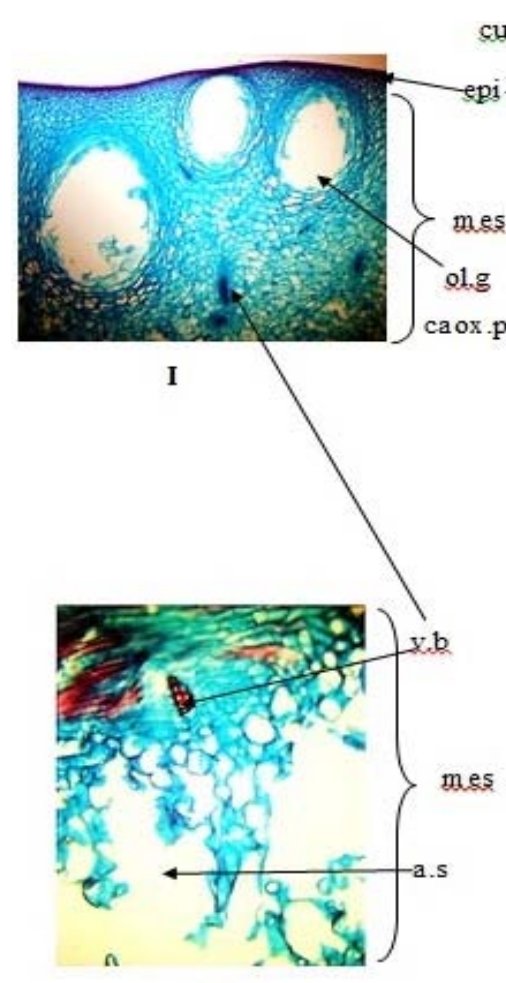

III

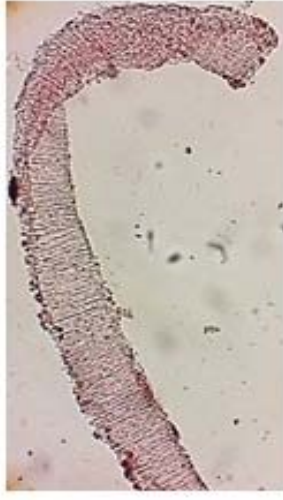

IV

Fig. 10: Micromorphology of $C$. maxima fruit. (I) Low power view of pericarp T. S. (X= 20), (II) High power view of epicarp and mesocarp T. S. (X=160), (III) High power view of mesocarp T. S. $(X=160)$, (IV) High power view of endocarp parenchyma cells $(X=400)$. a. S., air spaces; cut., cuticle; caox. pr., prisms of calcium oxalate; en. p., parenchymatous cells of endocarp; epi., epidermis; mes., mesocarp; o. gl., oil gland; vb., vascular bundle

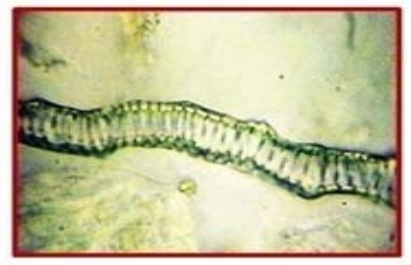

A

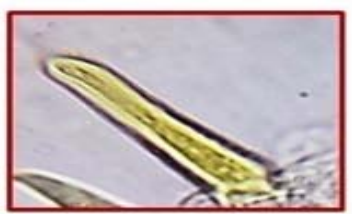

c

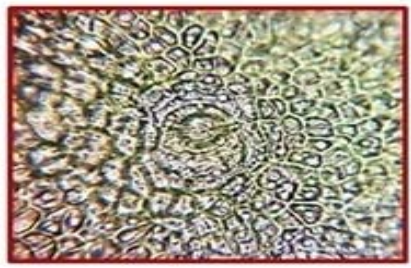

B

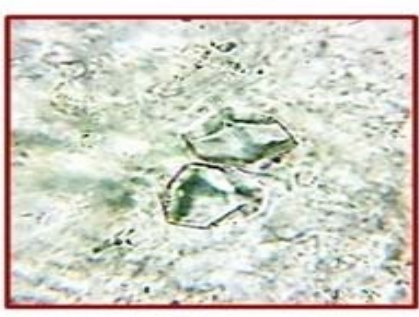

D

Fig. 11: Powdered fruit A., scalariform vessel (X=640); B., anomocytic stomata (X=400); C., Non-glandular unicellular hair. (X=160); $D$. , Prismatic crystal of Caox $(X=640)$

\section{The seed (fig. 12)}

A transverse section in the seed is formed of the testa, enclosing the embryo.

\section{The testa}

Formed of an outer seed coat and an inner seed coat. The outer seed coat consists of the outer epidermis which is formed of radially elongated cells with tapering ends; thick pitted lignified walls and their outer tangential walls had papillae and covered with a thick mucilaginous layer. The inner seed coat is formed of thin-walled parenchymatous cells followed by pigment layer composed of parenchymatous cells containing brown to reddish-brown pigments.

\section{The embryo}

Formed of several rows of polygonal thin-walled parenchymatous cells containing fixed oil globules and aleurone grains.

\section{Powdered seed (fig. 13)}

Powdered seeds is brownish yellow, odourless with an oily taste. Microscopically it is characterised by Fragments of epidermal cells 
showing papillose projection, fragments of polygonal cells of pigment layer, containing brown content, fragments of the parenchyma of the embryo cells containing fixed oil and aleurone grains, cells and numerous prismatic crystals of Calcium oxalate.

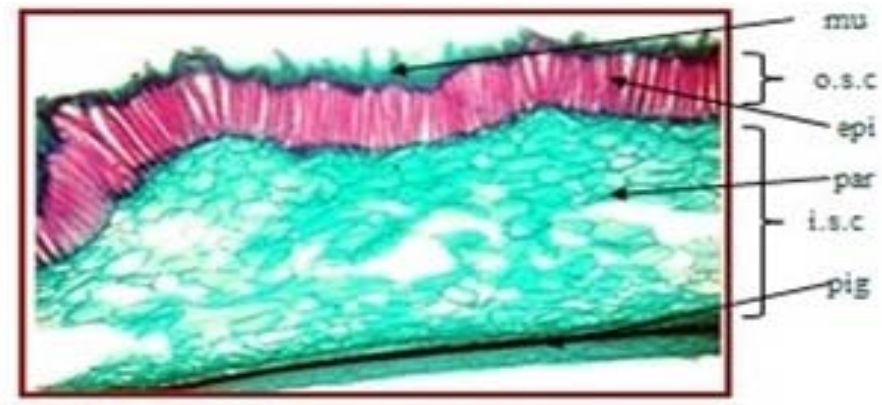

I

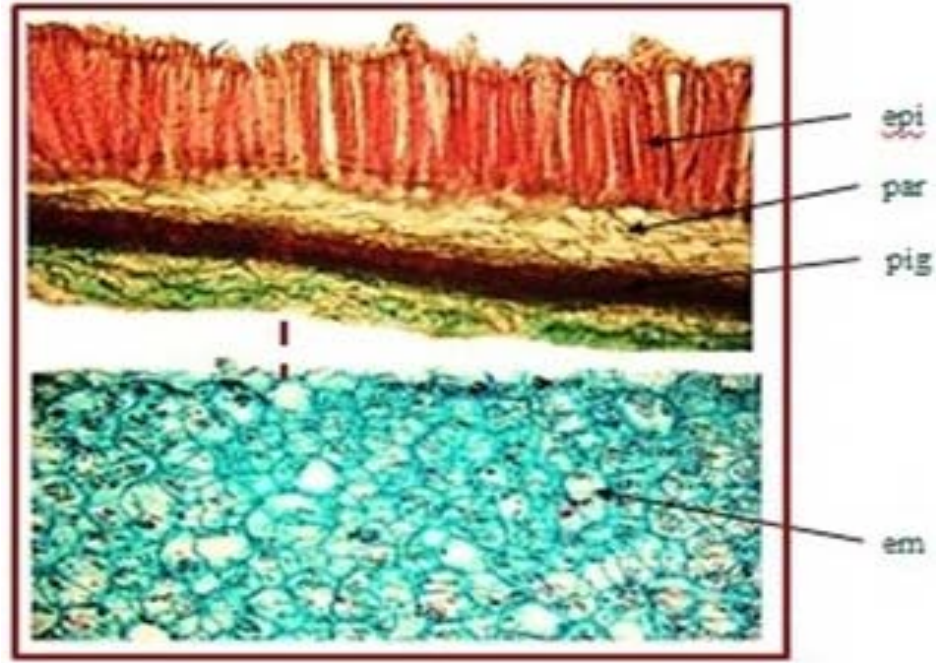

II

Fig. 12: Micromorphology of C. maxima fruit. (I) High power view of seed coat T. S. (X=100), (II) High power view of seed coat and embryo T. S. (X=160). em, embryo; epi., epidermis; ep. p, papillae of epidermis; i. s. c., inner seed coat; o. s. c., mu., mucilaginous layer; outer seed coat; par., parenchymatous cells; pig., pigment cells

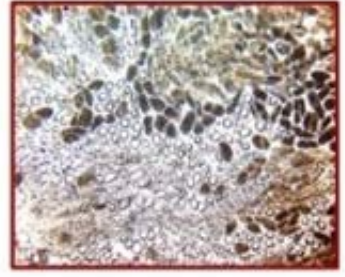

A

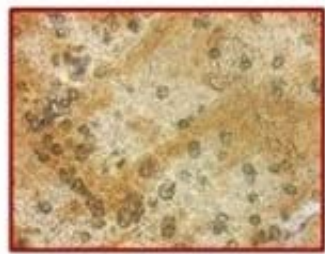

D

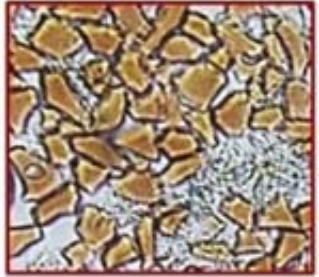

B

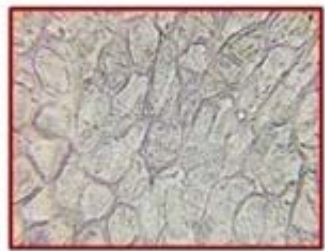

E

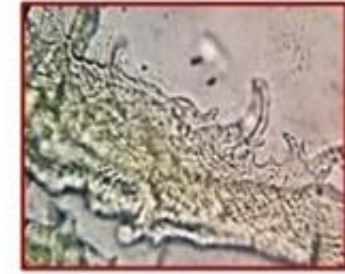

C

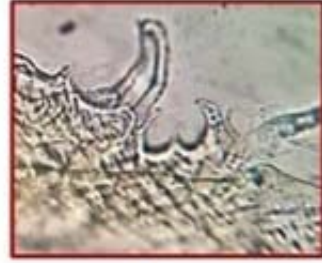

$\mathbf{F}$

Fig. 13: Powdered seed A., embryo showing aleurone grains ( $X=400)$; $B$. , brown pigment cells $(X=400)$; $C$. , epidermis showing papillosed projection ( $X=400)$; D., Prismatic crystal of Caox $(X=160)$; E., Fragment of thick walled parenchymatous cells $(X=400) ; F$., Epidermis showing papillosed projection that hold mucilage layer $(X=400)$ 


\section{Genetic profiling}

\section{DNA fingerprinting}

Genetic relationships as revealed by RAPD technique

The genetic similarity among Citrus maxima, Citrus paradisi and Citrus sinensis ranged from 73.8 to 85.7. The genetic relationship between (Citrus maxima and Citrus paradisi) and (Citrus paradisi and Citrus sinensis) proved high genetic similarity. While Citrus maxima and Citrus sinensis showed the lowest similarity.

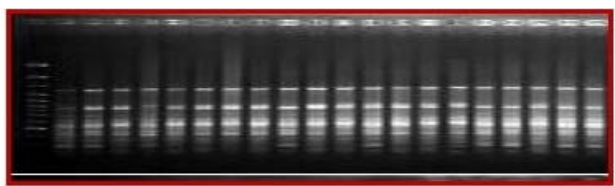

A: ISSR profiles for the Citrus maxima as detected with primers $\mathrm{Dl}, \mathrm{C1}$, 7. Z4. 28 . $77.84 .814, N 16$ and C15.

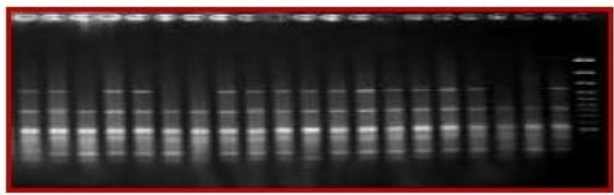

B: ISSR profiles for the Citrus paradisi as detected with primers $\mathrm{Dl}, \mathrm{Cl7}, \mathrm{ZZ}, \mathrm{Z}$ $\mathrm{E}, \mathrm{A} 7, \mathrm{~B} 4, \mathrm{B14}, \mathrm{N} 16$ and $\mathrm{C} 15$.

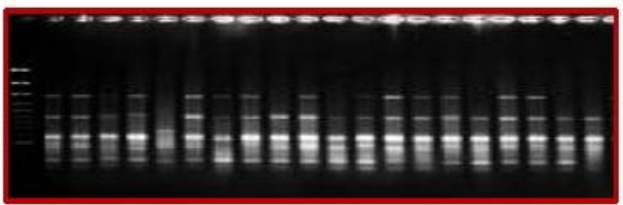

C: ISSR profiles for the Cirrus sinensis as detected with primers $\mathrm{D} 1, \mathrm{C} 17$,
$\mathrm{Z} 2 . \mathrm{Z4}$. Z8. A7. B4. B14. N16 and C15

Fig. 14: RAPD analysis of Citrus maxima, Citrus paradisi and Citrus sinensis

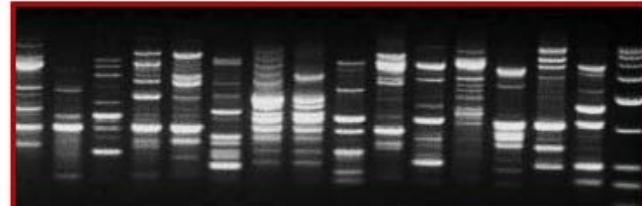

A: RAPD profiles for the Citus maxima as detected with primers $\mathrm{Dl}, \mathrm{Cl}$, $\mathrm{Z} 2, \mathrm{Z} 4, \mathrm{Z} 8, \mathrm{~A} 7, \mathrm{~B} 4, \mathrm{~B} 14, \mathrm{~N} 16$ and $\mathrm{Cl} 15$

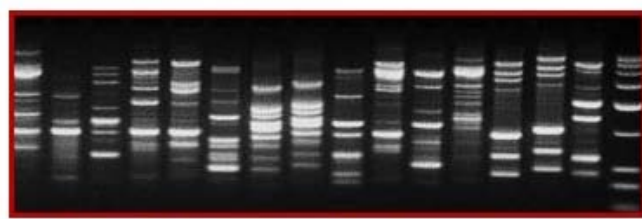

B: RAPD profiles for the Citrus paradisi as detected with primers $\mathrm{D} 1, \mathrm{C} 17$ $\mathrm{Z} 2, \mathrm{Z} 4, \mathrm{Z} 8, \mathrm{~A} 7, \mathrm{~B} 4, \mathrm{B14}, \mathrm{N} 16$ and $\mathrm{Cl}$

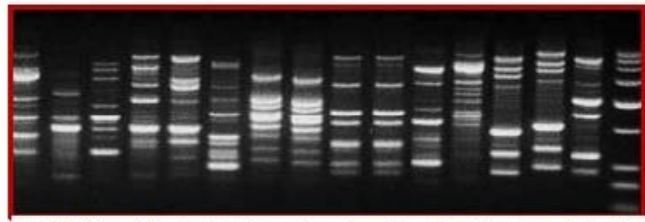

C: RAPD profiles for the Cimus sinensis as detected with primers D1, $\mathrm{Cl}$, $\mathrm{Z} 2, \mathrm{Z} 4, \mathrm{Z} 8, \mathrm{~A} 7, \mathrm{~B} 4, \mathrm{~B} 14, \mathrm{~N} 16$ and $\mathrm{C15}$

Fig. 15: ISSR analysis of Citrus maxima, Citrus paradisi and Citrus sinensis

\section{Genetic relationships as revealed by ISSR technique}

The genetic similarity among Citrus maxima, Citrus paradisi and Citrus sinensis ranged from 72.3 to 92.7. The genetic relationship between (Citrus maxima and Citrus paradisi) and (Citrus paradisi and Citrus sinensis) proved high genetic similarity. While Citrus maxima and Citrus sinensis showed lowest similarity.

Table 1: Dimensions (in microns) of different organs of Citrus maxima (Burm.) Merill

\begin{tabular}{|c|c|c|c|c|}
\hline Item & Length & Width & Height & Diameter \\
\hline \multicolumn{5}{|l|}{ Stem } \\
\hline Epidermal cells & $9-14-22$ & $7-11-18$ & $4-6-8$ & - \\
\hline Prisms of ca. ox & $12-23-28$ & $8-12-17$ & - & - \\
\hline Pericyclic fibers & $590-650-820$ & $8-27-39$ & - & - \\
\hline Phloem fibers & $300-460-570$ & $9-11-14$ & - & - \\
\hline Wood fibers & $285-380-560$ & $8-10-12$ & - & - \\
\hline Vessels & - & - & - & $7-10-25$ \\
\hline \multicolumn{5}{|l|}{ Root } \\
\hline Cork cells & $14-19-23$ & $10-14-18$ & $5-7-10$ & - \\
\hline Phloem fibers & $450-550-680$ & $14-17-20$ & - & - \\
\hline Wood fibers & $260-390-450$ & $9-12-14$ & - & - \\
\hline Vessels & - & - & - & $28-40-65$ \\
\hline \multicolumn{5}{|l|}{ Leaf lamina } \\
\hline Epidermal cells & - & - & - & - \\
\hline Upper epidermis & $11-19-31$ & $7-18-25$ & $5-8-10$ & - \\
\hline Lower epidermis & $8-15-23$ & $10-15-25$ & $7-12-14$ & - \\
\hline Stomata & $12-27-3$ & $7-10-20$ & - & - \\
\hline Pericyclic fiber & $290-420-500$ & $11-19-24$ & - & - \\
\hline Vessels & - & - & - & - \\
\hline \multicolumn{5}{|l|}{ Leaf petiole } \\
\hline Epidermal cells & $5-13-17$ & $4-7-10$ & $10-15-20$ & - \\
\hline Pericyclic fiber & $520-600-710$ & 8-19-22 & - & - \\
\hline Stomata & $20-24-28$ & $12-1722$ & - & - \\
\hline Vessels & - & - & - & $11-19-22$ \\
\hline Wood fiber & $260-340-410$ & $11-19-22$ & - & - \\
\hline \multicolumn{5}{|l|}{ Fruit } \\
\hline Epicarp & $6-12-19$ & $3-5-12$ & - & - \\
\hline Endocarp & - & - & $90-120-155$ & \\
\hline Oil gland & - & - & - & $33-98-130$ \\
\hline Vessels & - & - & - & $11-20-33$ \\
\hline \multicolumn{5}{|l|}{ Seed } \\
\hline Epidermal cells & $97-17-124$ & $18-22-30$ & - & - \\
\hline
\end{tabular}


Table 2: Numerical values of Citrus maxima (Burm.) Merill

\begin{tabular}{ll}
\hline Numerical value & Range \\
\hline Stomatal index & $9-12.5$ \\
Palisade ratio & $3-5.5$ \\
Vein-islet number & $12-15$ \\
\hline
\end{tabular}

Table 3: RAPD analysis of Citrus maxima, Citrus paradisi and Citrus sinensis

\begin{tabular}{|c|c|c|c|c|c|}
\hline \multirow[t]{2}{*}{ No. of primers } & \multirow[t]{2}{*}{ Primers code } & \multirow[t]{2}{*}{ Total number of band } & \multicolumn{2}{|c|}{ RAPD fragment score } & \multirow[t]{2}{*}{ Polymorphism \% } \\
\hline & & & Monomorphic & Polymorphic & \\
\hline 1 & D01 & 10 & 3 & 7 & 70.0 \\
\hline 2 & $\mathrm{C} 17$ & 7 & 3 & 4 & 57.1 \\
\hline 3 & $\mathrm{Z} 02$ & 13 & 6 & 7 & 53.8 \\
\hline 4 & $\mathrm{Z04}$ & 9 & 3 & 6 & 66.7 \\
\hline 5 & $\mathrm{Z} 08$ & 6 & 3 & 3 & 50.0 \\
\hline 6 & A07 & 9 & 3 & 6 & 66.7 \\
\hline 7 & B04 & 10 & 3 & 7 & 70.0 \\
\hline 8 & B14 & 8 & 3 & 5 & 62.5 \\
\hline 9 & N16 & 10 & 3 & 7 & 70.0 \\
\hline 10 & C15 & 7 & 3 & 4 & 57.1 \\
\hline 11 & A08 & 11 & 3 & 8 & 72.7 \\
\hline 12 & A09 & 8 & 3 & 5 & 62.5 \\
\hline 13 & A11 & 12 & 3 & 9 & 75.0 \\
\hline 14 & A14 & 5 & 3 & 2 & 40.0 \\
\hline 15 & B03 & 10 & 6 & 4 & 40.0 \\
\hline Total & & 135 & 51 & 84 & 62.2 \\
\hline Average per primer & & 9 & 3.4 & 5.6 & 4.15 \\
\hline
\end{tabular}

Table 4: ISSR analysis of Citrus maxima, Citrus paradisi and Citrus sinensis

\begin{tabular}{|c|c|c|c|c|c|}
\hline \multirow[t]{2}{*}{ No. of primers } & \multirow[t]{2}{*}{ primers code } & \multirow[t]{2}{*}{ Total number of band } & \multicolumn{2}{|c|}{ ISSR fragment score } & \multirow[t]{2}{*}{ Polymorphism \% } \\
\hline & & & Monomorphic & Polymorphic & \\
\hline 1 & Sh 1 & 7 & 3 & 4 & 57.14 \\
\hline 2 & Sh 2 & 12 & 6 & 6 & 50.00 \\
\hline 3 & Sh 3 & 13 & 3 & 10 & 76.92 \\
\hline 4 & Sh 4 & 11 & 6 & 5 & 45.45 \\
\hline 5 & Sh 5 & 5 & 0 & 5 & 100.00 \\
\hline 6 & Sh 6 & 15 & 6 & 9 & 60.00 \\
\hline 7 & Sh 7 & 17 & 6 & 11 & 64.71 \\
\hline 8 & Sh 8 & 9 & 3 & 6 & 66.67 \\
\hline 9 & Sh 9 & 10 & 3 & 7 & 70.00 \\
\hline 10 & Sh 10 & 8 & 3 & 5 & 62.50 \\
\hline 11 & M1 & 5 & 3 & 2 & 40.00 \\
\hline 12 & M5 & 11 & 3 & 8 & 72.73 \\
\hline 13 & M6 & 7 & 3 & 4 & 57.14 \\
\hline 14 & M9 & 5 & 3 & 2 & 40.00 \\
\hline 15 & M10 & 14 & 6 & 8 & 57.14 \\
\hline 16 & M16 & 11 & 3 & 8 & 72.73 \\
\hline 17 & UBC808 & 8 & 3 & 5 & 62.50 \\
\hline 18 & UBC810 & 10 & 3 & 7 & 70.00 \\
\hline 19 & UBC812 & 4 & 3 & 1 & 25.00 \\
\hline 20 & UBC813 & 11 & 3 & 8 & 72.73 \\
\hline Total & & 193 & 72 & 121 & 62.69 \\
\hline Average per primer & & 9.65 & 3.6 & 6.05 & 3.13 \\
\hline
\end{tabular}

Table 5: Genetic similarity matrices among Citrus maxima, Citrus paradisi and Citrus sinensis genotypes as computed according to Dice coefficient from RAPDs

\begin{tabular}{lll}
\hline RAPD & Citrus maxima & Citrus paradisi \\
\hline Citrus maxima & 100 & \\
Citrus paradisi & 85.7 & 100 \\
Citrus sinensis & 79.5 & 73.8 \\
\hline
\end{tabular}

Table 6: Genetic similarity matrices among Citrus maxima, Citrus paradisi and Citrus sinensis genotypes as computed according to Dice coefficient from ISSRs

\begin{tabular}{lll}
\hline ISSR & Citrus maxima & Citrus paradisi \\
\hline citrus maxima & 100 & \\
citrus paradisi & 92.7 & 100 \\
citrus sinensis & 76.2 & 72.3 \\
\hline
\end{tabular}


Table 7: Genetic similarity matrices among Citrus maxima, Citrus paradisi and Citrus sinensis genotypes as computed according to Dice coefficient from combined data

\begin{tabular}{llll}
\hline Combined & Citrus maxima & Citrus paradisi & Citrus sinensis \\
\hline citrus maxima & 100 & 100 & \\
citrus paradisi & 89.9 & 72.9 & 100 \\
citrus sinensis & 77.6 & & \\
\hline
\end{tabular}

Genetic relationships among the genotypes as revealed by combined data

The genetic similarity among Citrus maxima, Citrus paradisi and Citrus sinensis ranged from 72.9 to 89.9 (table 7). The highest genetic similarity (89.9) was between Citrus maxima and Citrus paradisi, while the lowest similarity (72.9) was between Citrus paradisi and Citrus sinensis.

\section{CONCLUSION}

For the present study, macro and micro-morphological characters, as well as, DNA fingerprinting can be considered as the identifying parameters for authentication of Citrus maxima (Burm.) Merrill. Where the genetic relationship between (Citrus maxima and Citrus paradisi) and (Citrus paradisi and Citrus sinensis) proved high genetic similarity and Citrus maxima and Citrus sinensis showed the lowest similarity using RAPD and ISSR technique and ISSR technique overcome most limitations of RAPD.

\section{CONFLICT OF INTERESTS}

Declared none

\section{REFERENCES}

1. Brechbill GO. The Citrus notes of the fragrance. Library of Congress, New Jersey, USA. Fragrance Books Inc; 2012.

2. Lim TK. Edible, medicinal and non-medicinal plants. 4, Fruits. Springer Netherlands; 2012.

3. Williams JK, Kubelik AR, Livak JK, Rafalski JA, Tingey SV. DNA polymorphisms amplified by arbitrary primers are useful as genetic markers. Nucleic Acids Res 1990;18:6531-5.

4. Godwin ID, Aitken EA, Smith LW. Application of inter simple sequence repeat (ISSR) markers to plant genetics. Electrophoresis 1997; 18:1524-8.

5. Pradeep-Reddy M, Sarla N, Siddiq EA. Inter-simple sequence repeat (ISSR) polymorphism and its application in plant breeding. Euphytica 2002;128:9-17.

6. Corazza-Nunes MJ, Machado MA, Nunes WMC, Cristofani M, Targon MLPN. Assessment of genetic variability in grapefruits
(Citrus paradisi Macf.) and pummelos (C. maxima Burm. Merr.) using RAPD and ISSR markers. Euphytica 2002;126:169-76.

7. The Citrus and Date Crop Germplasm Committee, USA (CDCGC) Citrus and Date Germplasm: Crop Vulnerability, Germplasm Activities, Germplasm Needs. Citrus and Date Crop Germplasm Committee, USA; 2004. p. 1-30.

8. Hamza M. Genetic diversity of some Citrus varieties based on microsatellite and RAPD molecular markers in Egypt. World J Agric Sci 2013;9:316-24.

9. Zietkiewicz E, Rafalski A, Labuda D. Genome fingerprinting by simple sequence repeat (SSR) anchored polymerase chain reaction amplification. Genomics 1994;20:176-83.

10. Gulsen 0 , Roose ML, Lemons: diversity and relationships with selected Citrus genotypes as measured with nuclear genome markers. J Am Soc Hortic Sci 2001;126:309-17.

11. Shahsavar AR, Izadpanah K, Tafazoli E, Tabatabaei BES. Characterization of Citrus germplasm including unknown variants by inter-simple sequence repeat (ISSR) markers. Sci Hort 2007;112:310-4.

12. Uzun A, Gulsen O, Yesıloglu T, Aka-Kacar Y, Tuzcu 0 . Distinguishing grapefruit and pummelo accessions using ISSR markers. Czech J Genet Plant Breed 2010;46:170-7.

13. Marak CK, Laskar MA. Analysis of the phonetic relationship between Citrus indica Tanaka and a few commercially important citrus species by ISSR markers. Sci Hort 2010;124:345-8.

14. Rana MK, Bhat KV. RAPD markers for genetic study among India cotton cultivars. Curr Sci 2005;88:1956-61.

15. Hussein EHA, Mohamed AA, Mohamed SA, Adawy SS. Molecular characterization and genetic relationship among cotton genotypes 1-RAPD, ISSR, and SSR analysis. Arab J Biotech 2006;9:222-9.

\section{How to cite this article}

- Mohammed S Sedeek, Farid N Kirollos, Camilia G Michel, Mostafa A Abdel-Kawy. Botanical and genetic characterization of Citrus Maxima (Burm.) Merrill. F. rutaceae. Int J Pharm Pharm Sci 2017;9(1):260-272. 